\title{
Effect of kaolinitic clays from the State of Rio de Janeiro in the composition of whiteware floor tile bodies
}

\section{(Efeito de argilas cauliníticas do Estado do Rio de Janeiro na composição de massa de pavimento cerâmico de base clara)}

\author{
C. M. F. Vieira, L. A. Peçanha Jr., S. N. Monteiro \\ Advanced Materials Laboratory - LAMAV, State University of the North Fluminense - UENF \\ Av. Alberto Lamego, 2000, Campos dos Goytacazes, RJ, 28015-602, Brazil \\ vieira@uenf.br
}

\begin{abstract}
This work presents an investigation that was undertaken for three types of kaolinitic clays from the State of Rio de Janeiro, Brazil, with a potential use in whiteware floor tiles bodies. Different compositions prepared by mixing the three clays with other materials such as kaolin, quartz, philite, potash feldspar and talc, were investigated and compared with an industrial ceramic body for whiteware floor tiles (group BIIa). Physical and mechanical properties such as linear shrinkage, water absorption and flexural strength were evaluated in pressed specimens fired at temperatures varying from 1025 to $1225^{\circ} \mathrm{C}$. The microstructure of the specimens was studied by X-ray diffraction, scanning electron microscopy and mercury porosimetry. The results indicated that the prepared compositions presented microstructural characteristics, specially the pore size distribution, and technological properties that are compatible with low-porosity ceramic tiles. However, they also display characteristics, such as an excessive plasticity and high loss on ignition, that could generate problems during the industrial processing.
\end{abstract}

Keywords: ceramic tiles, clay, kaolinite.

\section{Resumo}

Este trabalho apresenta uma investigação sobre três tipos de argilas cauliníticas do Estado do Rio de Janeiro, Brasil, com potencial uso em massas de pavimentos cerâmicos de base clara. Diferentes composições, preparadas através da mistura das três argilas com outros materiais, tais como quartzo, filito, feldspato potássico e talco, foram investigadas e comparadas com uma massa cerâmica industrial de pavimento de base clara (grupo BIIa). Propriedades físicas e mecânicas tais como retração linear, absorção de água e tensão de ruptura à flexão foram avaliadas em corpos de prova prensados e queimados em temperaturas variando de 1025 a $1225{ }^{\circ} \mathrm{C}$. A microestrutura das amostras foi avaliada por difração de raios X, microscopia eletrônica de varredura e porosimetria de mercúrio. Os resultados indicaram que as composições preparadas apresentam características microestruturais, especialmente a distribuição de tamanho de poro, e propriedades tecnológicas que são compatíveis com revestimentos cerâmicos de baixa porosidade. Entretanto, as composições também apresentam características, tais como uma excessiva plasticidade e elevada perda de massa, que podem gerar problemas durante o processamento industrial.

Palavras-chave: revestimento cerâmico, argila, caulinita.

\section{INTRODUCTION}

Ceramic bodies used for whiteware floor tiles fabrication are normally composed of a complex mixture of different raw materials [1-4]. In addition to silica, alumina and alkaline oxides, which are basic components for this class of products, iron compounds, carbonates, organic matter and sulfur may also be present. However, these other non-basic materials should not be present in amounts higher than the limits established for the industrial practice [5]. The raw materials can be grouped in two classes: plastic and nonplastic. The plastic raw materials are essentially the clays and the kaolin that have, as their main function, to supply plasticity and to provide adequate mechanical strength for both, the green and dried body pieces. In addition, the plastic materials must present favorable rheological properties for an efficient wet milling stage [4].

Among the non-plastic raw materials, feldspars, talc and quartz are the most used. All of them decrease the plasticity, facilitate the defloculation, enhance the packing and increase the permeability of the pieces. During the firing stage, the feldspars act as a flux supplying alkaline oxides $\left(\mathrm{K}_{2} \mathrm{O}+\right.$ $\left.\mathrm{Na}_{2} \mathrm{O}\right)[3,4,6-8]$. Others fluxes that are also used in partial or total substitution for feldspars are philite, phonolite, nepheline and granite. Talc is introduced in low amounts to increase the flux of the body through eutectic formation with alkaline feldspars $[9,10]$. During the firing stage, the quartz has the function of balancing the ratio between $\mathrm{SiO}_{2}$ 
and $\mathrm{Al}_{2} \mathrm{O}_{3}$ in other to favor the formation of mullite [11]. It increases the refractoriness and, in general, also increases the expansion coefficient of the body and so decreasing the linear shrinkage [4]. Quartz, with small particle size in the range of 10-30 $\mu \mathrm{m}$, improves the mechanical strength. By contrast, larger-sized quartz particles tend to decrease the mechanical strength due to the susceptibility to micro-cracks formation. This is a consequence of the allotropic transformation, which results in volumetric change at temperatures around $573{ }^{\circ} \mathrm{C}$ [12-15]. Low amounts of carbonates such as calcite and dolomite are also used to increase the fluxing action and enhance the moisture expansion.

The objective of this work was to evaluate the use of three types of kaolinitic clays from the State of Rio de Janeiro as potential raw materials for whiteware floor tiles composition.

\section{EXPERIMENTAL PROCEDURE}

The three clays in the present investigation were collected from the municipal areas of Silva Jardim and Campos dos Goytacazes, both located in the State of Rio de Janeiro. The clays were denoted as white (Silva Jardim), black (Campos) and carolinho (Campos). The other raw materials, such

Table I - Chemical composition of the industrial raw materials (wt.\%).

[Tabela I - Composição química das matérias-primas industriais (\% em peso).]

\begin{tabular}{lccccc}
\hline & Kaolin & Quartz & Philite & Feldspar & Talc \\
\hline $\mathrm{SiO}_{2}$ & 44.2 & 99.66 & 69.48 & 66.8 & 62.0 \\
$\mathrm{Al}_{2} \mathrm{O}_{3}$ & 40.2 & 0.15 & 16.39 & 18.3 & 0.01 \\
$\mathrm{Fe}_{2} \mathrm{O}_{3}$ & 0.34 & 0.04 & 2.26 & 0.1 & 0.07 \\
$\mathrm{TiO}_{2}$ & 0.5 & 0.01 & 0.6 & 0.01 & 0.01 \\
$\mathrm{MgO}$ & 0.09 & - & 3.22 & 0.1 & 32.3 \\
$\mathrm{CaO}$ & - & - & - & - & 0.01 \\
$\mathrm{~K}_{2} \mathrm{O}$ & 0.41 & - & 4.42 & 8.13 & 0.01 \\
$\mathrm{Na}_{2} \mathrm{O}$ & 0.38 & - & 0.09 & 3.7 & 0.01 \\
$\mathrm{LoI}$ & 15.0 & 0.25 & 5.0 & 0.01 & 5.0 \\
\hline
\end{tabular}

as kaolin, quartz, philite, potash feldspar and talc were obtained from mining facilities outside the State of Rio de Janeiro. Table I shows the chemical composition of these raw materials.

The three clays were initially characterized in terms of their mineralogical composition by X-ray diffraction (XRD), chemical composition, X-ray fluorescence (XRF) and by the plasticity limits according to Brazilian standards $[16,17]$. The XRD of randomly-oriented powder was carried out in a Seifert model URD 65, diffractometer, equipped with a graphite monochromator operating with $\mathrm{Cu}-\mathrm{K}_{\alpha}$ radiation for a $2 \theta$ range from $5^{\circ}$ to $40^{\circ}$. The XRF was conducted in a Philips PW 2400 equipment.

Three experimental body compositions named X1, X2 and $\mathrm{X} 3$ were prepared varying the amount of clays while maintaining the amount of other materials constant. The raw materials were mixed according to the selected amounts shown in Table II.

For a comparative study, an industrial body IB, used in the fabrication of whiteware floor tiles (group BIIa), was obtained from a ceramic industry in S. Paulo. This typical industrial body was elaborated from a mixture of plastic kaolinitic clays, ilitic clay, philite, talc and calcite [4].

The experimental bodies were initially wet-milled in porcelain pots during two hours. The slurries were then sieved through 325 mesh $(44 \mu \mathrm{m})$ and allowed to dry at $110{ }^{\circ} \mathrm{C}$ until $8 \%$ of humidity was achieved. The powder was screened through a 20 mesh $(820 \mu \mathrm{m})$ sieve.

Rectangular specimens measuring $114.3 \times 25.4 \times 10 \mathrm{~mm}^{3}$ were prepared by uniaxial pressing in the range of 25 to 30 MPa to assure that all specimens would have a bulk density of $1.97 \pm 0.03 \mathrm{~g} / \mathrm{cm}^{3}$. This was intended to guarantee that the degree of compactness of the bodies was always the same and did not influence the microstructure and, consequently, the evaluated properties. Initially, specimens were dried at $110^{\circ} \mathrm{C}$ until a constant weight was achieved and then fired at temperatures in the range of 1025 to $1225^{\circ} \mathrm{C}$. A controlled heating rate of $10{ }^{\circ} \mathrm{C} / \mathrm{min}$ was maintained up to the desired temperature, at which each specimen was left for $6 \mathrm{~min}$. The cooling was performed by natural convection after turning the furnace off and leaving the specimen inside. The evaluated properties were water absorption, linear shrinkage

Table II - Prepared bodies (wt.\%).

[Tabela II - Massas preparadas (\% em peso).]

\begin{tabular}{ccccccccc}
\hline \multicolumn{10}{c}{ Raw materials } \\
\hline Compositions & $\begin{array}{c}\text { white } \\
\text { clay }\end{array}$ & $\begin{array}{c}\text { black } \\
\text { clay }\end{array}$ & $\begin{array}{c}\text { carolinho } \\
\text { clay }\end{array}$ & kaolin & quartz & philite & feldspar & talc \\
A & 35 & - & - & 5 & 5 & 35 & 15 & 5 \\
B & 15 & 10 & 10 & 5 & 5 & 35 & 15 & 5 \\
C & - & 17.5 & 17.5 & 5 & 5 & 35 & 15 & 5 \\
\hline
\end{tabular}


and flexural strength. The water absorption was determined according to standard procedure [18]. The linear shrinkage was obtained by the length of the samples before and after the firing stage using a caliper with precision of $\pm 0.01 \mathrm{~mm}$. The flexural rupture strength was determined by the three point bending test in a universal Instron 5582 machine, following standard procedures [19].

Microstructural analysis of the experimental and industrial ceramic bodies was performed in specimens fired at $1175^{\circ} \mathrm{C}$.

The fracture surface of a few selected fired samples was studied by scanning electron microscopy (SEM) using a Zeiss model DSM 962 equipment. A pore size distribution between 0.00648 to $8.8884 \mu \mathrm{m}$ was obtained by mercury intrusion porosimetry, using a contact angle of $140^{\circ}$, in an Autoscan 33 Quantachrome Porosimeter. Major crystalline phases were determined by XRD in sectioned pieces, collected from the center of fired specimens, according to the previously described parameters employed for the unfired materials.

\section{RESULTS AND DISCUSSION}

\section{Characteristics of the clays}

Fig. 1 shows the XRD patterns of the raw materials. These diffraction patterns indicate that all clays are predominantly kaolinitic. The presence of quartz as well as a micaceous mineral and gibbsite is also observed as common constituents for all clays. Potash feldspar peaks were only significant in the white clay.

Table III presents the chemical composition of the three clays. It should be noted that all clays display higher contents of $\mathrm{SiO}_{2}$ and $\mathrm{Al}_{2} \mathrm{O}_{3}$. The $\mathrm{SiO}_{2} / \mathrm{Al}_{2} \mathrm{O}_{3}$ ratio indicates the amount of clay minerals i.e., those with particle size $<2 \mu \mathrm{m}$, present in the clays. The $\mathrm{SiO}_{2} / \mathrm{Al}_{2} \mathrm{O}_{3}$ ratio of 1.96 in the carolinho clay, suggests a greater amount of sand as compared to the white, 1.72 , and black, 1.67 , clays. The relatively lower amount of $\mathrm{Fe}_{2} \mathrm{O}_{3}$ in the white clay is an indication that this clay is more adequate to the fabrication of ceramic products with lighter color. The white clay has also the greater amount of $\mathrm{K}_{2} \mathrm{O}$, which conveniently forms a liquid phase that contributes to densification at high temperatures. The amount of $\mathrm{TiO}_{2}$, similar in all clays, is considered normal

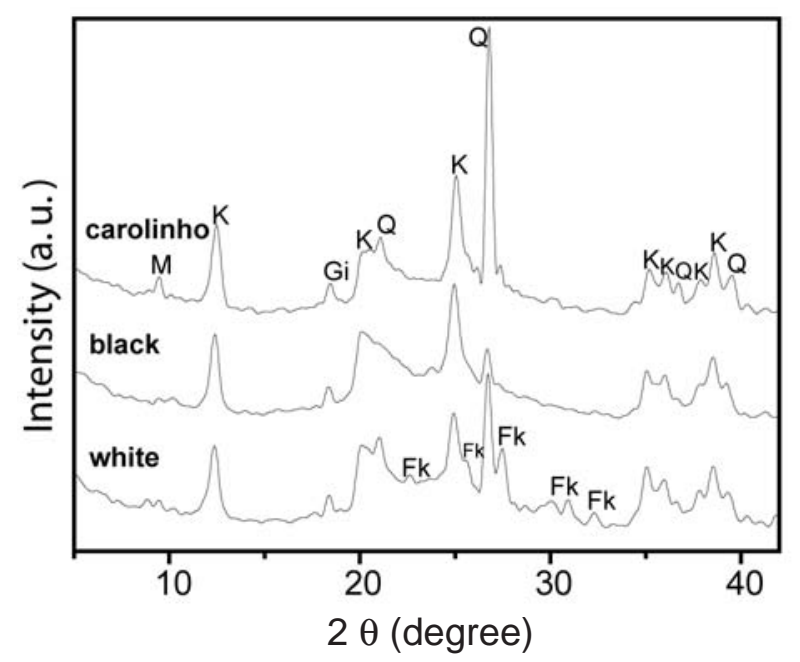

Figure 1: XRD patterns of the clays. $\mathrm{Fk}=$ potash feldspar; $\mathrm{K}=$ kaolinite; $\mathrm{M}=$ micaceous mineral; $\mathrm{Q}=$ quartz.

[Figura 1: Difratogramas de raios $X$ das argilas. $F k=$ feldspato potássico; $K=$ caulinita; $M=$ mineral micáceo; $Q$ = quartzo.]

but may cause a yellowish color that is not satisfactory for whitewares. The loss on ignition (LoI) is an indicative of the relative proportion between plastic and non-plastic compounds in the clay. The higher LoI value for the black clay is due to its high amounts of clay minerals. Moreover, the greater contribution from organic carbon $(0.72 \%)$ could also add to the LoI of the black clay and result in black core defects in the final ceramic product. Another factor related to the relatively larger value of LoI for all clays is the existence of gibbsite (aluminum hydroxide) indicated by the XRD, as shown in Fig. 1.

The general evaluation of the results presented in Table III is that all compositions are typical of kaolinitic clays. In terms of a potential for whiteware floor tiles production the white clay can be considered the most suitable one.

Table IV shows the plasticity of all investigated clays given by the Atterberg limits. The lower plastic limit (LPL) is associated with the minimum amount of water that is needed to a clay attends a convenient plastic state. The upper plastic limit (UPL) is related to the amount of water for which the clay behaves like a low viscosity fluid and, therefore, cannot be formed by extrusion or pressing. The plasticity index

Table III - Chemical composition of the clays (wt.\%).

[Tabela III - Composição química das argilas (\% em peso).]

\begin{tabular}{lcccccccccc}
\hline Clays & $\mathrm{SiO}_{2}$ & $\mathrm{Al}_{2} \mathrm{O}_{3}$ & $\mathrm{Fe}_{2} \mathrm{O}_{3}$ & $\mathrm{TiO}_{2}$ & $\mathrm{MgO}$ & $\mathrm{CaO}$ & $\mathrm{K}_{2} \mathrm{O}$ & $\mathrm{Na}_{2} \mathrm{O}$ & $\mathrm{LoI}$ & $\mathrm{C}^{*}$ \\
white & 52.10 & 30.30 & 1.76 & 1.25 & 0.30 & 0.13 & 3.34 & 0.30 & 10.20 & 0.06 \\
black & 48.73 & 29.20 & 2.22 & 1.61 & 0.58 & 0.41 & 0.61 & 0.27 & 16.34 & 0.72 \\
carolinho & 54.27 & 27.71 & 3.51 & 1.27 & 0.88 & 0.27 & 1.88 & 0.35 & 10.26 & 0.06 \\
\hline
\end{tabular}

${ }^{*} C=$ organic carbon 
Table IV - Plasticity of the clays (\%).

[Tabela IV - Plasticidade das argilas (\%).]

\begin{tabular}{lccc}
\hline \multicolumn{3}{c}{ Atterberg limits } \\
\hline Clays & LPL & UPL & PI \\
white & 27 & 59 & 32 \\
black & 33 & 81 & 48 \\
carolinho & 24 & 51 & 27 \\
\hline
\end{tabular}

(PI) corresponds to the difference between the UPL and the LPL values. The greater the PI is, the higher the clay's plasticity will be. In practice, this indicates that more water can be added to the clay without changing its plasticity state. Suitable PI values for clay used in ceramic tiles vary form 10 to $25 \%$ [3]. Comparing the PI values in Table IV, it might be concluded that they are above the recommended limit.

\section{Characteristics of the bodies}

Table $\mathrm{V}$ presents the chemical compositions of both, the prepared experimental bodies and the industrial body, IB. When IB is compared to the experimental bodies, it shows lower amounts of $\mathrm{Al}_{2} \mathrm{O}_{3}$ and higher $\mathrm{Fe}_{2} \mathrm{O}_{3}$ and $\mathrm{CaO}$ contents. The large amount of $\mathrm{Fe}_{2} \mathrm{O}_{3}$ is mainly due to the industrial use of ilitic fluxing clays, which normally have an iron oxide concentration above 5 wt.\%. The large amount of $\mathrm{CaO}$ is due to the calcite in the body composition. When calcite is added into the vitrified tiles composition, it acts as a whitener material and decreases the vitrification temperature [20]. However, the experimental bodies show greater $\mathrm{Na}_{2} \mathrm{O}$ and $\mathrm{MgO}$ contents. The potash feldspar with $3.7 \%$ of sodium oxide used in these $\mathrm{X}$ bodies is responsible for the larger amount of $\mathrm{Na}_{2} \mathrm{O}$. The talc, added to form a low temperature eutectic with the potash feldspar, was the main reason for a larger $\mathrm{MgO}$ content.

For the specific purpose of whiteware floor tiles, the experimental bodies are within the chemical specifications. However, for stoneware porcelain tiles (group BIa) that require pronounced whiteness, the experimental bodies have excessive $\mathrm{Fe}_{2} \mathrm{O}_{3}$ content when compared to industrial formulation for group BIa products [21]. An up-grade of these bodies would require the elimination of the carolinho clay with $3.51 \%$ of $\mathrm{Fe}_{2} \mathrm{O}_{3}$. Moreover, the philite should be totally replaced by feldspar.

\section{Technological properties of the compositions}

Fig. 2 presents the behavior of the linear shrinkage as a function of the firing temperature for all investigated bodies. It can be seen that they all show similar behavior with a comparatively greater increment in the linear shrinkage above $1075{ }^{\circ} \mathrm{C}$. This can be attributed to the formation of a liquid phase that fills the porosity and promotes the approximation of the particles.

Fig. 3 presents the water absorption as a function of the firing temperature for all investigated bodies. It should be remembered that the water absorption can be used to evaluate the sintering process of ceramics and has an important role in the classification of ceramic tiles [21]. In this figure one can see that all bodies show a decrease in the water absorption with increasing temperature. This is a consequence of the

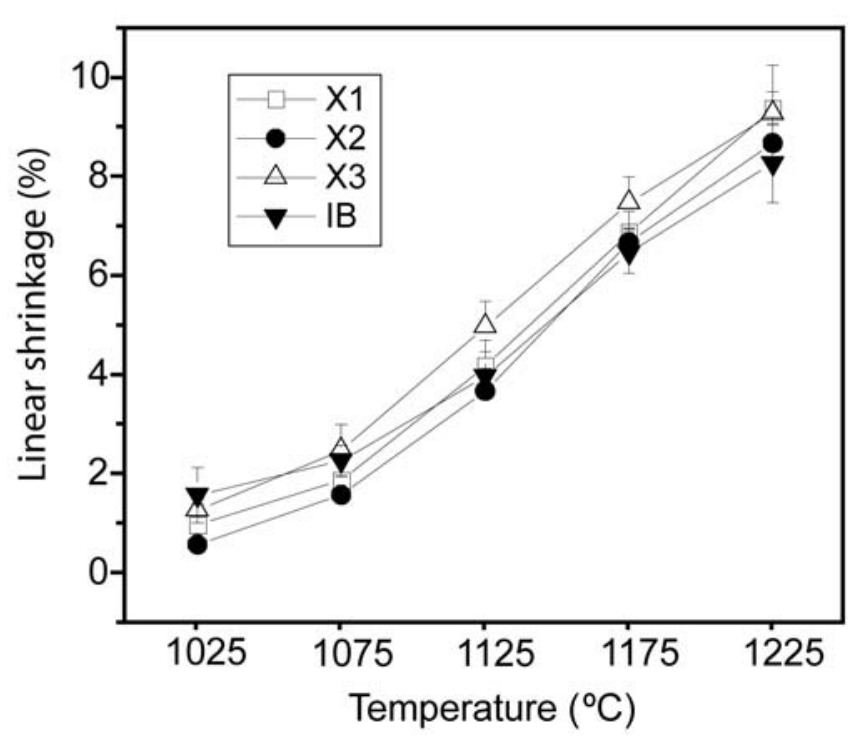

Figure 2: Linear shrinkage of the bodies as a function of the firing temperature.

[Figura 2: Retração linear das massas em função da temperatura de queima.]

Table V - Chemical composition of the studied bodies (wt.\%).

[Tabela V - Composição química das massas estudadas (\% em peso).]

\begin{tabular}{cccccccccc}
\hline Compositions & $\mathrm{SiO}_{2}$ & $\mathrm{Al}_{2} \mathrm{O}_{3}$ & $\mathrm{Fe}_{2} \mathrm{O}_{3}$ & $\mathrm{TiO}_{2}$ & $\mathrm{MgO}$ & $\mathrm{CaO}$ & $\mathrm{K}_{2} \mathrm{O}$ & $\mathrm{Na}_{2} \mathrm{O}$ & LoI \\
\hline $\mathrm{X} 1$ & 62.87 & 21.10 & 1.44 & 0.68 & 2.87 & 0.05 & 3.96 & 0.71 & 6.33 \\
$\mathrm{X} 2$ & 62.75 & 20.74 & 1.67 & 0.71 & 2.95 & 0.09 & 3.54 & 0.71 & 6.95 \\
$\mathrm{X} 3$ & 62.66 & 20.46 & 1.83 & 0.74 & 3.02 & 0.12 & 3.22 & 0.71 & 7.42 \\
$\mathrm{IB}$ & 62.77 & 19.04 & 2.62 & 1.16 & 2.11 & 1.89 & 3.84 & 0.26 & 6.13 \\
\hline
\end{tabular}




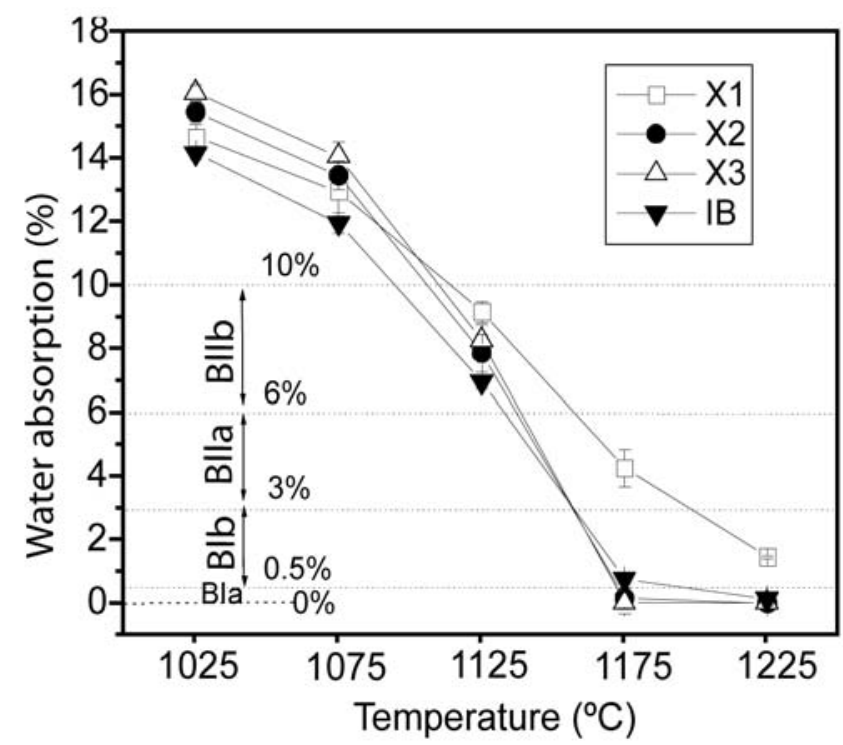

Figure 3: Water absorption of the bodies as a function of firing temperature.

[Figura 3: Absorção de água das massas em função da temperatura de queima.]

reduction in the open porosity associated with both, solid state and liquid phase formation sintering processes [22]. The latter predominates at higher temperatures. It should be noticed that IB presents the lowest values of water absorption up to approximately $1150{ }^{\circ} \mathrm{C}$. Above this, bodies X2, X3 and IB show similar values of water absorption. In particular, body X1 shows the greatest water absorption above $1110^{\circ} \mathrm{C}$, which can be attributed to its more refractory behavior. In spite of the larger fluxing $\mathrm{K}_{2} \mathrm{O}$ content of this body, the high percentage of $\mathrm{Al}_{2} \mathrm{O}_{3}$ is apparently causing its refractoriness. Moreover, $\mathrm{X} 1$ presents the lowest $\mathrm{Fe}_{2} \mathrm{O}_{3}$ content, Table $\mathrm{V}$, which could also act as a fluxing agent if transformed to $\mathrm{FeO}$ [23].

Fig. 3 also indicates the intervals of water absorption associated with the different classification for ceramic floor tiles groups [21]. With the exception of body X1, the others present values of water absorption within the specification for whiteware floor tiles at temperatures normally employed by industries.

Fig. 4 presents the flexural rupture strength as a function of the firing temperature for all investigation bodies. It should be reminded that the mechanical strength is strongly dependent on the microstructure, especially on defects such as pores and cracks. Furthermore, together with the water absorption, it also has an important role in the classification of floor tiles [21]. Fig. 4 shows that all bodies present an increase in strength with firing temperature. The only exception is IB at $1225^{\circ} \mathrm{C}$, possibly due to the frequently occurring phenomenon of overfiring. Nevertheless, the industrial body displays the highest values of strength at all temperatures. This behavior, up to $1150{ }^{\circ} \mathrm{C}$, can be attributed to a lower porosity, as discussed in terms of the data from Fig. 3. Beyond $1150^{\circ} \mathrm{C}$, the level of porosity in IB is similar to those in $\mathrm{X} 2$ and $\mathrm{X} 3$, and the greater strength of IB could be attributed to the amount and type of phases in the bodies. At these higher temperatures mullite and residual quartz crystals dispersed in a vitreous matrix are expected to be formed. This aspect will be later discussed in the present paper.

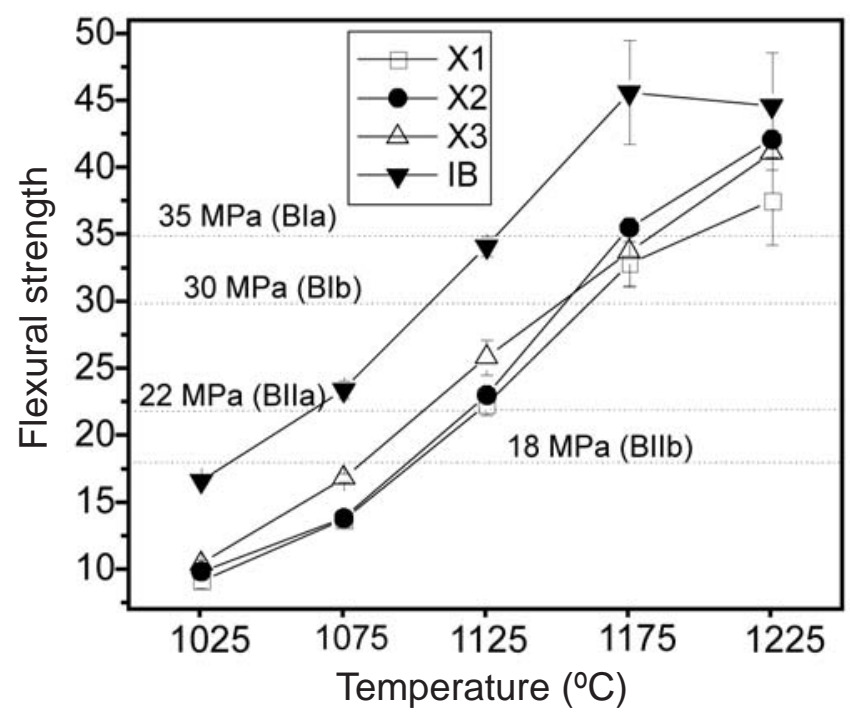

Figure 4: Flexural strength of the bodies as a function of firing temperature.

[Figura 4: Tensão de ruptura à flexão das massas em função da temperatura de queima.]

Fig. 4 also indicates the intervals of strength associated with the different types of groups for ceramic floor tiles [21]. All investigated bodies are within the ranges of strength required for the classified groups of ceramic tiles at temperatures similar to those employed by industries.

\section{Microstructure of the bodies}

A microstructural analysis was carried out only for bodies fired at $1175^{\circ} \mathrm{C}$, which is a typical temperature employed by industries in the production of BIb group ceramics, such as whitewares. This analysis was performed by XRD to identify the crystalline phases, mercury porosity to evaluate the open porosity, and SEM to observe the fracture surfaces.

Fig. 5 shows the pore size distribution of different bodies fired at $1175{ }^{\circ} \mathrm{C}$. One should notice that the $\mathrm{X} 1$ material presents, comparatively, the greatest volume of open pores. This explains the largest value of water absorption, Fig. 3, at that firing temperature. It could also be seen in Fig 5 that the IB material has pores with larger sizes. This result is apparently related to preferred removal of smaller pores at the beginning of the sintering process [24].

Figs. 6a to $6 \mathrm{~d}$ show the fracture surface of different bodies fired at $1175^{\circ} \mathrm{C}$. The main feature in these figures is the presence of well-distributed small pores in the structure. In particular, it is relevant to note that the X1 body prepared with white clay, Fig. 6a, apparently displays a greater porosity. This is in agreement with corresponding results on $\mathrm{Hg}$ porosimetry and water absorption. 


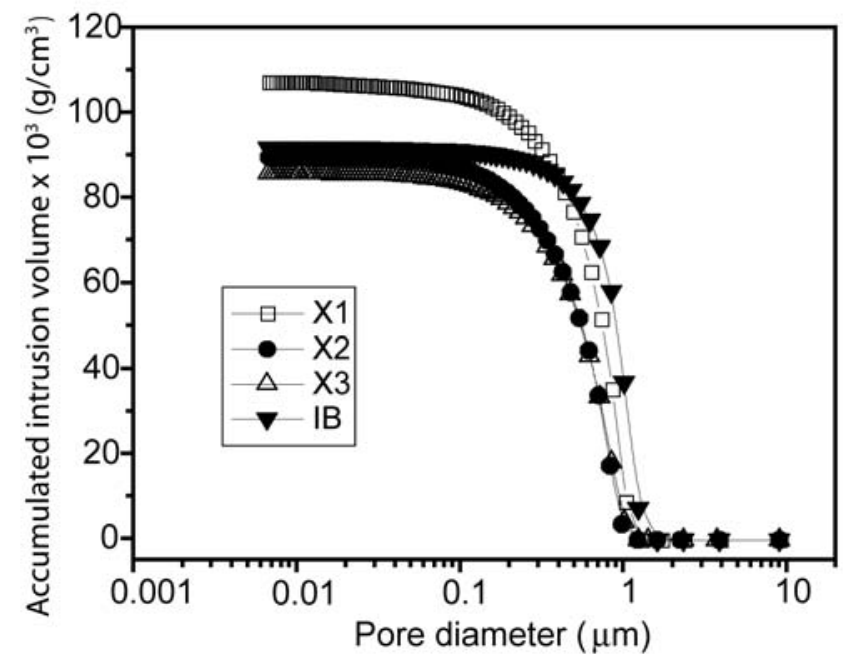

Figure 5: Accumulated pore-size distribution curves of the bodies. [Figura 5: Curvas de distribuição de tamanho de poros das massas.]
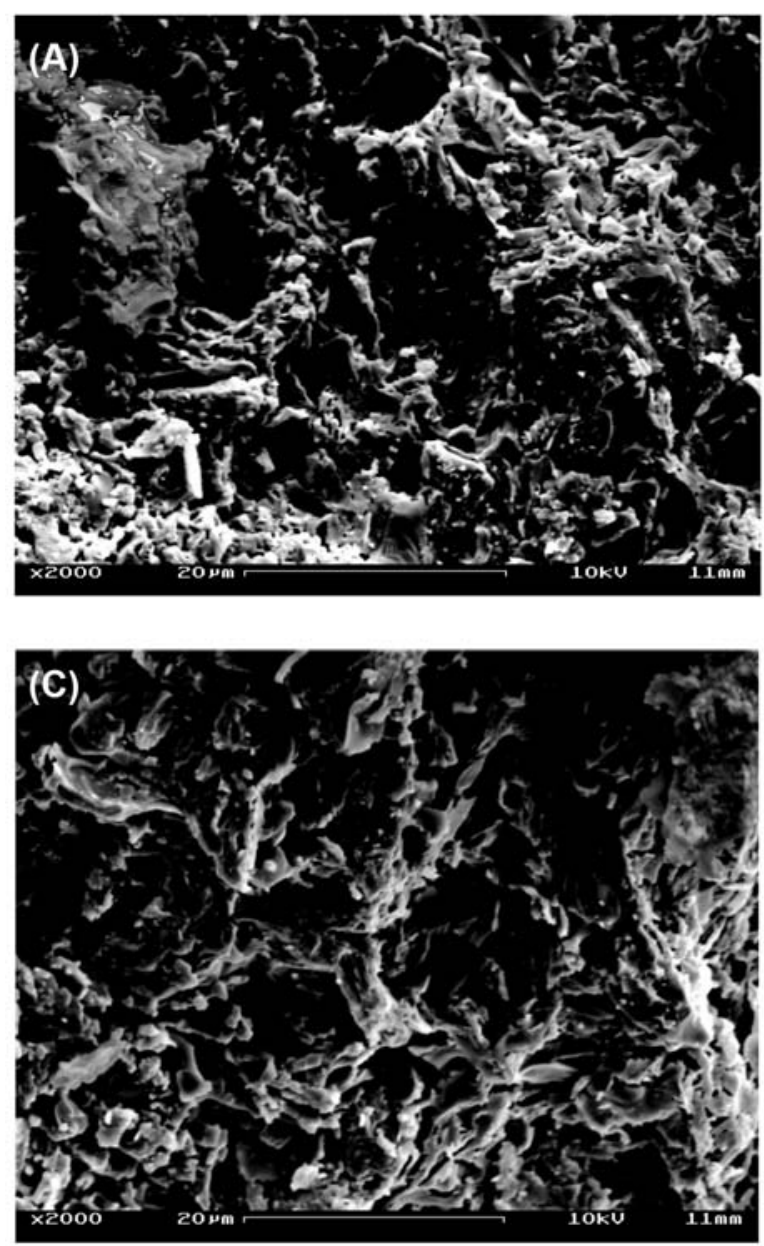

Fig. 7 shows the XRD pattern of different bodies fired at $1175{ }^{\circ} \mathrm{C}$. In general, all bodies present similar crystalline phases. The identified common phases were quartz, potash feldspar and mullite. While the first two are residual phases from the raw materials mineralogical composition, the mullite comes from the metakaolinite decomposition around $950^{\circ} \mathrm{C}$. In the spectrum of IB material a plagioclase, probably albite due to the elevated amount of $\mathrm{CaO}$, was also detected. In scientific investigations performed at temperatures above $1150{ }^{\circ} \mathrm{C}$, it is a common feature for clayey bodies to have a microstructure formed by mullite crystals and residual quartz [25]. However, the presence of potash feldspar, found at $1175{ }^{\circ} \mathrm{C}$ in Fig. 7 , is a clear indication that this level of temperature was not enough to promote its complete dissolution. In principle this dissolution should have occurred around $1150{ }^{\circ} \mathrm{C}$ through an incongruent melting [8]. In this respect, the lesser intensity of the potash feldspar XRD peaks in IB is apparently a consequence of its higher amount of glassy phase, contributing to elevate the mechanical strength.
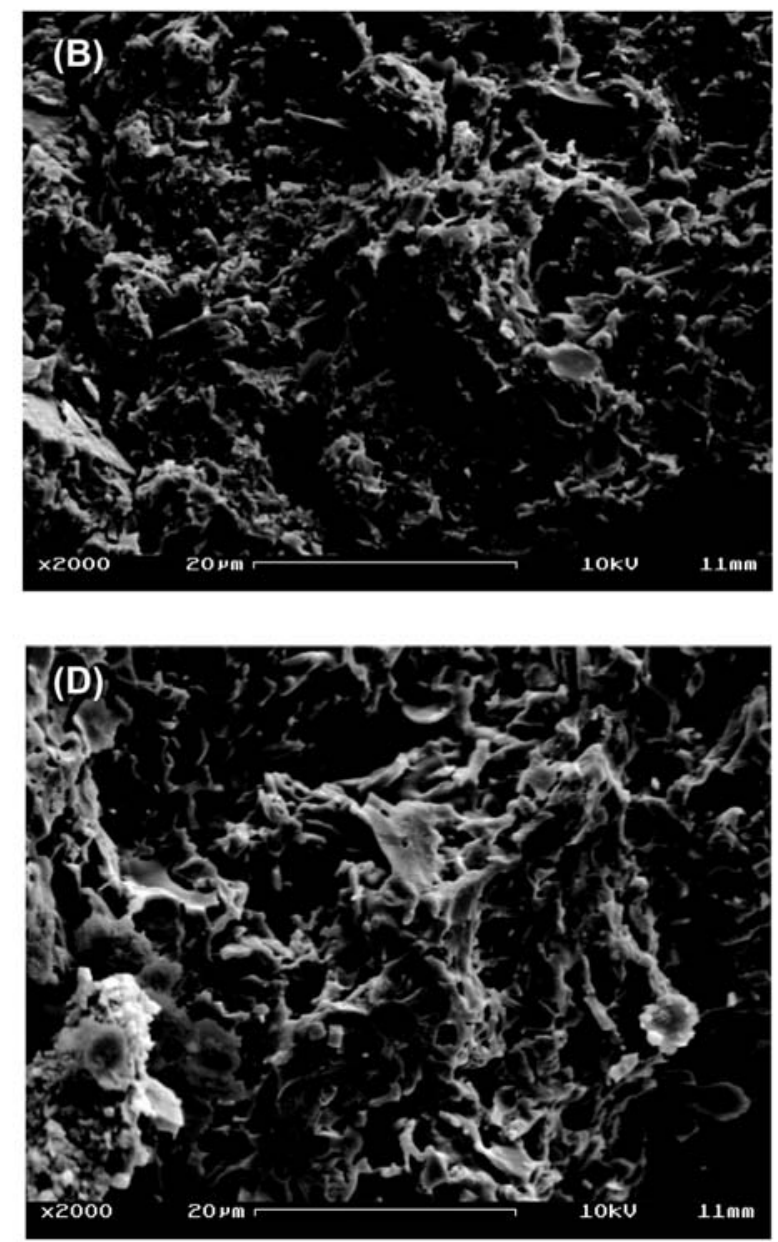

Figure 6: SEM micrographs of the fracture surface of the compositions fired at $1175^{\circ} \mathrm{C}$. (A) X1; (B) X2; (C) X3; (d) industrial body IB. [Figura 6: Micrografias obtidas por MEV da superficie de fratura das massas queimadas a $1175{ }^{\circ} \mathrm{C}$. (A) X1; (B) X2; (C) X3; (d) massa industrial IB.] 

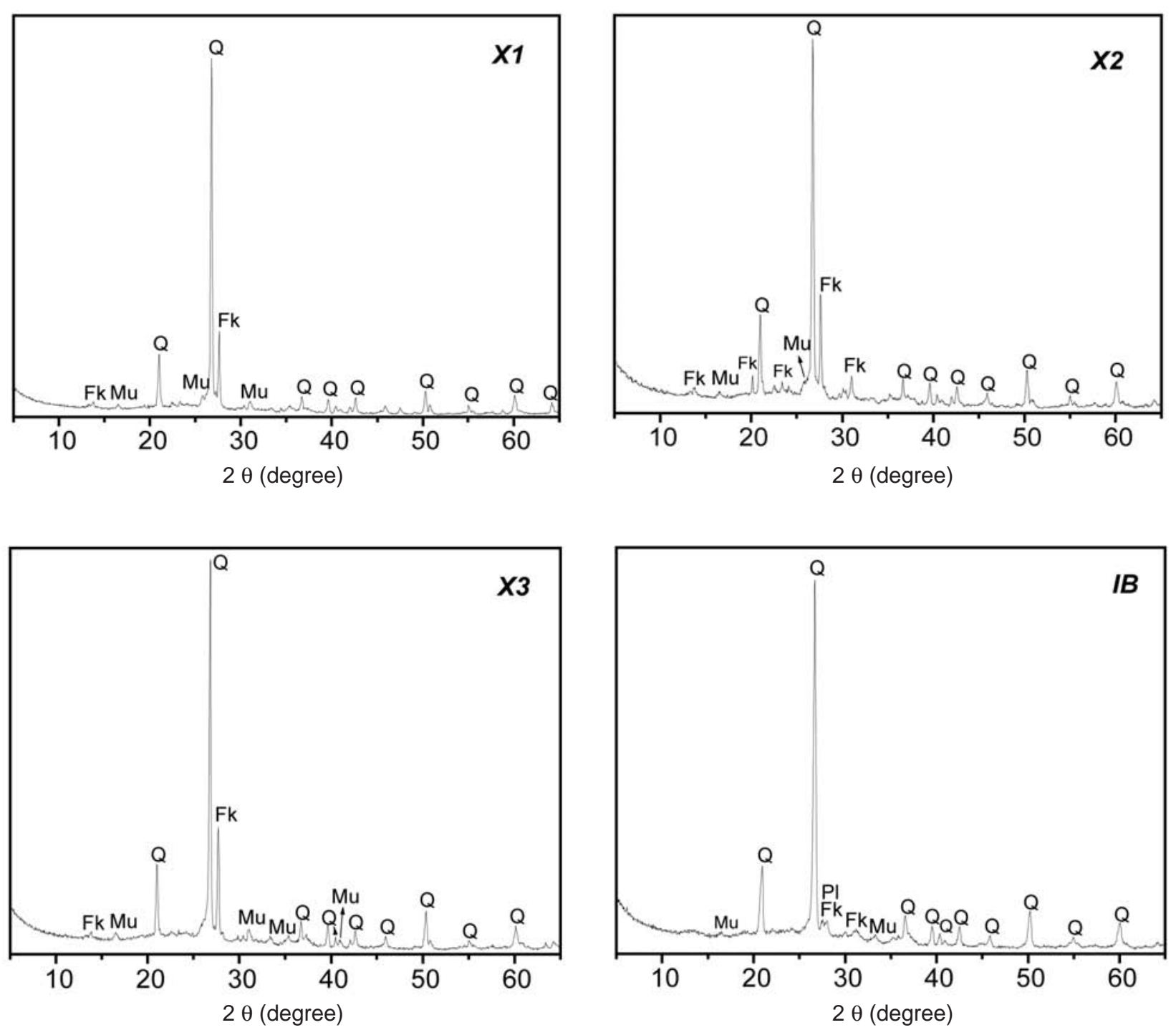

Figure 7: XRD patterns of the bodies fired at $1175^{\circ} \mathrm{C}$. Fk = potassic feldspar; $\mathrm{Mu}=$ mullite; $\mathrm{Q}=$ quartz; $\mathrm{Pl}=$ plagioclase. [Figura 7: Difratogramas de raios X das massas queimadas a $1175^{\circ} \mathrm{C}$. Fk = feldspato potássico; $\mathrm{Mu}=$ mulita; $Q=$ quartzo; $\mathrm{Pl}$ = plagioclásio.]

\section{CONCLUSIONS}

A technological and scientific investigation on the possibility of using three typical kaolinitic clays from the state of Rio de Janeiro, Brazil, in ceramic bodies to fabricate whiteware floor tiles has led to the following conclusions: in a large scale production, the refractory characteristics of all clays are responsible for the comparatively poorer properties of the fired ceramics. Their excessive plasticity can also result in problems at the forming stage and make it difficult to achieve the required body permeability.

In particular, the high weight loss of the black clay can be associated with defects in the final product such as voids, cracks and dimensions out of specifications. The high amount of $\mathrm{Fe}_{2} \mathrm{O}_{3}$ of the carolinho clay can result in undesired color for the ceramic support. The white clay appears to be the most adequate, among the three, to be used in whiteware floor bodies although it may cause excessive water absorption at elevated temperatures.

In a general analysis, the experimental bodies presented similar characteristics, as well as similar properties and microstructures to an industrial body normally used for whitewares floor tiles in Brazil.

\section{ACKNOWLEDGMENTS}

The authors would like to thank CNPq, CAPES, FAPERJ and TECNORTE/FENORTE. 


\section{REFERENCES}

[1] A. E. Benlloch, J. L. A. Albaro, J. E. E. Navarro, Bol. Soc. Esp. Ceram. Vidr. 20 (1981) 17.

[2] J. E. E. Navarro, J. L. A. Albaro, Técnica Cerámica 91 (1981) 119.

[3] E. Sanchéz, J. Garcia, F. Ginés, F. Negre, Cerâmica Industrial 1 (1996) 13.

[4] A. Barba, V. Beltrán, C. Feliu, J. García, F. Ginés, E. Sánchez, V. Sanz, Materias primas para la fabricación de soportes de baldosas cerámicas, Instituto de Tecnologia Cerámica-AICE, Castellón (1997) p. 291.

[5] D. Minichelli, G. Polizzotti, Tile \& Brick Int. 9 (1993) 141.

[6] N. M. Kruglitsky, B. M. Datsenko, B. I. Moroz, Ceram. Int. 10 (1984) 78.

[7] A. A. Mostafa, E. H. Sallam, H. El Didamony, D. M. Ibrahim, Tile \& Brick Int. 10 (1994) 340.

[8] G. P. Emiliani, F. Corbara, Tecnología Cerámica - La Lavorazione, Gruppo Editoriale Faenza Editrice, Faenza (1999) p. 97.

[9] D. M. Ibrahim, A. A. Khalil, S. M. H. Naga, Nepheline syenite-talc low temperature vitrified bodies, Ceram. Int. 7 (1981) 69.

[10] T. K. Mukhopadhyay, M. Das, S. Ghosh, S. Chakrabarti, S. Ghatak, Ceram. Int. 29 (2003) 587.

[11] G. Biffi, Porcelain stoneware - Production manual and methods of use, Gruppo Editoriale Faenza Editrice S. p. A., Faenza (1999) p. 304.

[12] S. I. Warshaw, R. Seider, J. Am. Ceram. Soc. 50 (1967) 337.

[13] Y. Kobayashi, O. Ohira, Y. Ohashi, E. Kato, J. Am.
Ceram. Soc. 75 (1992) 1801.

[14] V. Kilikoglou, G. Vekinis, Y. Maniatis, Acta Metall. Mater. 43 (1995) 2959.

[15] S. Maity, B. K. Sarkar, J. Eur. Ceram. Soc. 16 (1996) 1083.

[16] Associação Brasileira de Normas Técnicas (ABNT), Determinação do limite de plasticidade de solos, NBR 645984, Rio de Janeiro (1984).

[17] Associação Brasileira de Normas Técnicas (ABNT), Determinação do limite de liquidez de solos, NBR 7180-84, Rio de Janeiro (1984).

[18] American Society for Testing and Materials (ASTM), Water Absorption, Bulk Density, Apparent Porosity, and Apparent Specific Gravity of Fired Whiteware Products, C 373-72 (1972).

[19] American Society for Testing and Materials (ASTM), Flexural Properties of Ceramic Whiteware Materials, C 67477 (1977).

[20] V. Beltrán, E. Sánchez, J. García-Ten, E. Ginés, Técnica Cerámica 241 (1996) 114.

[21] Associação Brasileira de Normas Técnicas (ABNT), Placas Cerâmicas para Revestimento - especificação e métodos de ensaio, NBR - 13818, Rio de Janeiro (1997).

[22] O. Delbrouck, J. Janssen, R. Ottenburgs, P. Van Oyen, W. Viaene, Appl. Clay Sci. 8 (1993) 187.

[23] M. P. Abajo, Manual Sobre Fabricación de Baldosas Tejas y Ladrillos, Beralmar, S. A., Terrassa (2000) p. 22.

[24] M. J. Ortz, A. Escardino, J. L. Amorós, F. Negre, Appl. Clay Sci. 8 (1993) 193.

[25] T. K. Mukhopadhyay, M. Das, S. Ghosh, S. Chakrabarti, S. Ghatak, Ceram. Int. 29 (2003) 587.

(Rec. 27/11/2004, Rev. 20/04/2005, Ac. 03/01/2006) 